\title{
Knowledge Level of Participant TMI Members on Technological and Environment Aspects
}

\author{
Ashok Doddamani*, M. A. Yashashwini and C. M. Savitha \\ Department of Agricultural Extension, College of Agriculture, University of Agricultural \\ Sciences, GKVK, Bangalore-560065, India
}

*Corresponding author

Keywords

Knowledge,

TMI members,

Technological and

environment aspects

Article Info

Accepted:

12 December 2020

Available Online:

10 January 2021

\section{A B S T R A C T}

There are 36,672 tanks in the state with an irrigation potential of 6.85 lakh hectares. These tanks were and continue to be the lifeline of village communities, to meet diverse range of their requirements-agricultural and non-agricultural. The study was conducted in Bagepalli taluk of Chikballapur district, Mulbagal taluk of Kolar district, Pavagada taluk of Tumkur district and Chitradurga (Kasaba) taluk of Chitradurga district of Karnataka. A majority (51.67\%) of FFS respondents belonged to the category of medium in overall knowledge level on technological aspects, whereas, 31.67 per cent and 16.67 per cent respondents belonged to high and low overall knowledge level on technological aspects, respectively. Overall knowledge level of participant TMI members on environmental aspects, a majority $(53.33 \%)$ belonged to high followed by medium $(38.35 \% 0$ and low $(8.33 \%)$ category knowledge level by FFS respondents. Overall knowledge level of participant TMI members on technological and environmental aspects indicated that, a majority $(68.33 \%)$ of FFS respondents belonged to high knowledge level category followed by medium (18.33\%) and low (13.33\%) knowledge level category.

\section{Introduction}

Karnataka state like many other states in the country, is endowed with a number of tanks, to harvest surface run off in the watersheds at the micro level. There are 36,672 tanks in the state with an irrigation potential of 6.85 lakh hectares. These tanks were and continue to be the lifeline of village communities, to meet diverse range of their requirementsagricultural and non-agricultural. Traditionally, the communities had evolved their own ways and means of managing the tanks, keeping environmental and ecological balance in view. Based on the politico economy considerations and requirements in the post-independence period, as mentioned earlier, the management of tank systems has 
gradually been taken over by the government. With the result, the traditionally practiced community based management systems, and strategies, sustained for generations, have slowly been discontinued due to a number of socio-economic and cultural factors. This has gradually developed dependency syndrome among hitherto self-propelling communities. Over a period of time, due to a variety of natural, economic and social constraints, the decaying of tank systems has started in the state, like elsewhere in the country. For instance, tanks which used to overflow or discharge every year, or even twice a year in some cases, have not been getting filled once in 5 years or 10 years, or even more.

\section{Materials and Methods}

The study was conducted in Chikballapur, Kolar, Tumkur and Chitradurga district of Karnataka. Since Bagepalli (Chikballapur) and Mulbagalu (Kolar) taluks have more number beneficiaries of On-farm demonstrations on water management (WMD), arable crops (ACD), horticultural crops (HCD) and farmer field school (FFS) were selected for the study while Pavagada (Tumkur) and Chitradurga (Chitradurga) taluks did possess less number of beneficiaries of On-farm demonstrations and FFS were selected to match the respondents. Respondents were selected based on multistage random sampling technique. Sixty beneficiaries from WMD, 60 beneficiaries from ACD and 32 beneficiaries from HCD were selected based on the on-farm demonstrations conducted at the ratio of $2: 2: 1$ (WMD: ACD: HCD) as per the norms of KCBTMPCS and from FFS also 60 beneficiaries were selected. Thus, the study was conducted with 212 respondents wherein each taluk one village for WMD, one village for $\mathrm{ACD}$, one village for $\mathrm{HCD}$ and one village for FFS was selected based on the highest number of beneficiaries. From each village 15 respondents was selected through random sampling technique. But, in HCD only 8 respondents was selected, constituting a total sample size of 212.

\section{Results and Discussion}

The data presented in table 1 revealed that, a majority $(51.67 \%)$ of FFS respondents belonged to the category of medium in overall knowledge level on technological aspects, whereas, 31.67 per cent and 16.67 per cent respondents belonged to high and low overall knowledge level on technological aspects, respectively. In case of WMD respondents it was noticed that 43.33 per cent had medium overall knowledge level followed by low $(31.67 \%)$ and high (25.00\%) level category. Further, 45.00 per cent of the ACD respondents belonged to the category of medium overall knowledge level on technological aspects followed by low $(33.33 \%)$ and high (21.67\%) level. With regard to $\mathrm{HCD}$ respondents a majority $(53.13 \%)$ of the respondents had medium overall knowledge level followed by high (31.25\%0 and low (15.63\%) knowledge level on technological aspects. In general 47.64 per cent of respondents belonged to medium knowledge level of technological aspect whereas, 26.89 per cent of respondents coming under high knowledge level category and 25.47 per cent of the respondents belonged to the category of low knowledge level.

It is clear from the table that the overall knowledge level of participant TMI members on environmental aspects, a majority (53.33\%) belonged to high followed by medium $(38.35 \% 0$ and low $(8.33 \%)$ category knowledge level by FFS respondents. The WMD respondents belonged to 38.33 per cent medium level knowledge on environmental aspects category followed by low (33.33\%) and high $(28.33 \%)$ knowledge level category. 
Further, a great majority $(63.33 \%)$ of the ACD respondents were seen in low level category followed medium and high $(18.33 \%$ each) knowledge level category. While, half per cent of HCD respondents belonged to high knowledge level category followed by medium (37.50\%) and low (12.50\%) category. Among the total number of respondents 35.85 per cent had high knowledge level on environmental aspects while, 32.55 per cent respondents were medium and 31.60 per cent respondents grouped under low knowledge level category.

Overall knowledge level of participant TMI members on technological and environmental aspects indicated that, a majority $(68.33 \%)$ of FFS respondents belonged to high knowledge level category followed by medium (18.33\%) and low (13.33\%) knowledge level category. The respondents from WMD were in low (36.67\%) knowledge level on technological and environmental aspect whereas 35.00 per cent had high and 28.33 medium knowledge level category. A majority (58.33\%) ACD respondents had low knowledge level followed by high $(25.00 \%)$ and medium (16.67\%) knowledge regarding technological and environmental aspects. While, 59.38 per cent of HCD respondents belonged high knowledge level category and one fourth belonged to medium and only 15.63 per cent had low knowledge level. In general, the overall knowledge level of participant TMI members on technological and environmental aspects with 45.28 per cent respondents belonged to high knowledge level and 33.02 per cent belonged to low knowledge level and only 21.70 per cent belonged to medium knowledge level category.

The CBTMPCS had conducted various method demonstrations in the village itself, organized study tours, exhibitions, conducted on-farm demonstrations, field visits etc., for TMI members through FFS, WMD, ACD and
WMD in the project area. These activities have has influenced the knowledge level of farmers. Needed technical know-how would not be available to farmers under village situation unless some special efforts are made to educate them. This trend evidently shows that the knowledge components which are cost effective and easy to practice are known to all farmers while components which are complex, high cost and needs skill to practice are known to few percent of respondents. The findings of Borkar et al., (2000), Vinod Gupta et al., (2001) Shinde, (2002) and Sasidhar Reddy et al., (2007) on various subjects can be quoted to support the results.

The data presented in table 2 revealed that, cent per cent of the FFS respondents had knowledge about following proper spacing, weeding and earthing up, staking at one month after transplanting and staking at three months after transplanting. A great majority of the FFS respondents had knowledge regarding staking at two months after transplanting $(93.33 \%)$ and same response $(91.67 \%)$ from the respondents given to variety, ridges and furrow method of irrigation, frequency of irrigation and number of irrigation aspects. The knowledge level on drip irrigation, skip furrow method of irrigation, flooding type of irrigation, seed rate, alternate furrow method of irrigation, broad bed and furrow method of irrigation aspects was to the extent of $90.00 \%, 86.67 \%$, $85.00 \%, 85.00 \%, 81.67 \%$ and $80.00 \%$ by the respondents, respectively. The FFS respondents who answered as " don't know" for tray method of nursery $(38.33 \%)$ followed by season $(25.00 \%)$, raised bed nursery $(21.67 \%)$, broad bed and furrow method of irrigation $(20.00 \%)$, alternate furrow irrigation $(18.33 \%)$, seed rate and flooding method of irrigation (15.00\%) and skip furrow method of irrigation (13.33\%). Equal response $(8.33 \%)$ from respondents was received to frequency of irrigation, number of 
irrigation, ridges and furrows method of irrigation and variety aspects.

Cent per cent of the WMD respondents expressed that they know about the season, variety, on and off method of irrigation, frequency of irrigation and weeding and earthing up practices. A great majority $(93.33 \%)$ of the respondents had knowledge about the flooding type of irrigation followed by alternate furrow method of irrigation (91.67\%), drip irrigation (87.67\%), skip row method of irrigation $(80.00 \%)$, ridges and furrows method of irrigation $(78.33 \%)$ and staking at one month after transplanting (76.67 \%). Equal number $(73.33 \%)$ of respondents had knowledge about the seed rate, proper spacing, broad bed and furrow method of irrigation and staking at three months transplanting technologies. One third of the respondents expressed as "don't know" to the raised bed nursery followed by tray method of nursery (31.67\%), staking at two months after transplanting $(30.00 \%)$ and same number of respondents $(26.67 \%)$ had response for seed rate, spacing, broad bed and furrow method of irrigation and staking at three months after transplanting.

The ACD respondents, had cent per cent 'knowledge' about the technological aspects like season (Kharif/rabi), frequency of irrigation, number of irrigation, and weeding and earthing up. A large majority (91.67\%) of respondents did know about the raised bed nursery and broad bed and furrow method of irrigation followed by skip furrow method of irrigation $(90.00 \%)$. Further, it was noticed that 85.00 per cent of respondents had knowledge about the alternate furrow method of irrigation, whereas 83.33 per cent of respondents know about the staking at two months after transplanting, 81.67 per cent of the respondents know about on and off method of irrigation. It was seen that, 80.00 per cent of the respondents gave response to tray method of nursery, spacing and staking at one month after transplanting. The response to variety was 'don't know' by 35.00 per cent of respondents followed by to the practice like ridges and furrows method of irrigation (26.67 \%), flooding irrigation $(25.00 \%)$, seed rate, drip irrigation and staking at three months transplanting $(21.67 \%)$ and on and off method of irrigation $(18.33 \%)$. Equal number $(20.00 \%)$ of respondents had knowledge about the tray method of nursery, spacing and staking at one month after transplanting.

Cent percent of HCD respondents expressed that they had knowledge about the season (kharif/rabi), alternate furrow method of irrigation, on and off method irrigation, frequency of irrigation, weeding and earthing up technological aspects. Majority of the respondents had knowledge regarding spacing (96.88 \%) followed by equal number $(90.63$ $\%$ ) of respondents did know about broad bed and furrow method of irrigation and number of irrigation. As many as 87.50 per cent of respondents did know about the seed rate, ridges and furrow method of irrigation, skip furrow method of irrigation, flooding type of irrigation and drip irrigation technological aspects. The response as don't know was expressed to staking at three months after transplanting where as 37.50 percent of respondents followed staking at one month after transplanting (31.25\%). Similarly, same (12.50\%) number of respondents "did not know" about the seed rate, ridges and furrow method of irrigation, skip furrow method of irrigation, flooding type of irrigation and drip irrigation technological aspects.

The overall knowledge of respondents was cent per cent with regard to weeding and earthing up aspects. A great majority of the respondents did know the frequency of irrigation (97.64\%) followed by season (kharif/rabi, 92.92\%), number of irrigation 
(92.45\%), on and off method of irrigation $(88.68 \%)$, alternate furrow method of irrigation (88.21\%),spacing (86.32\%), skip furrow method of irrigation $(85.85 \%)$ and variety as well as drip irrigation method $(85.38 \%)$, respectively. Further, 84.91 per cent respondents had knowledge about flooding method of irrigation, whereas, 83.06 per cent of respondents know the broad bed and furrow method of irrigation as well as staking at one month after transplanting and also 82.08 per cent know the ridges and furrow method and staking at two months after transplanting technologies. As many as 80.19 per cent respondents did know about the seed rate followed by 80.66 per cent about the staking at three months after transplanting and 79.25 percent respondents know about the raised bed nursery technology. On the other hand, 29.72 percent of the respondents "did not know" about the tray method of nursery technology, followed by 20.75 percent on raised bed nursery, 19.81 percent on seed rate, 19.34 per cent on stacking at three months after transplanting and 16.98 percent about broad bed furrow method of irrigation technologies, respectively. Only a few respondents did not had knowledge about the technology of frequency of irrigation (2.36 percent), followed by season (7.08 percent) and number of irrigations (7.55 percent). It was interesting to note that majority of farmers had better knowledge on weeding and earthing up, frequency of irrigation, correct season, number of irrigation, on and off method of irrigation, alternate furrow method of irrigation, maintaining proper spacing, skip furrow method of irrigation, using suitable variety, drip irrigation method, flooding method of irrigation, broad bed and furrow method of irrigation, crop staking, ridges and furrow method of irrigation, correct seed rate, tray method of nursery and raised bed nursery. This implies the influence of project activities in the tank command areas to increase farmers knowledge. The findings are in line with the findings of the study Ahmed and Phillip (1999), Sudhakar and Kanagasabapathi (2002), Gogoi et al., (2000), Kubde et al., (2000) and Vinay Kumar et al., (2009)

A glance at the table-3 shows that, cent per cent of FFS respondents had "knowledge" under INM aspects viz applying organic manures like tank silt followed by FYM/compost and vermicompost, whereas, 86.7 percent respondents know about the neem cake and 81.7 percent respondents know about the green manure, respectively. Cent percent WMD respondents had knowledge about the FYM/compost organic manure under INM technology followed by neem cake $(95.05 \%)$, tank silt $(90 \%)$ and vermicompost as well as green manure (86.7\%). Regarding ACD respondents it was noticed that cent per cent did know about the tank silt and compost/ FYM organic manure application followed by green manure $(85.0$ percent), vermicompost (80\%) and neem cake $(63.3 \%)$ of the respondents. Similarly, cent per cent of the HCD respondents had knowledge about the FYM/compost, vermicompost and green manures application under INM, while same number of respondents $(87.5 \%)$ had knowledge about the neem cake and tank silt application technology. In general, cent per cent respondents had knowledge about FYM/compost organic manure application under INM followed by tank silt $(95.30 \%)$, vermicompost $(90.6 \%)$, green manure $(86.8 \%)$, and neem cake $(82.5 \%)$, respectively. This point out that FFS, WMD, ACD and HCD activities has influenced the knowledge level of farmers. Thus when special efforts were made by the way of training, demonstration, field visits, exhibition, study tour etc., as project activities, farmers acquire more knowledge about the agricultural new technologies. 
With regard to biofertilizer application the respondents had knowledge about applying azospirillum (91.7\%), followed by application of azotobacter $(88.3 \%)$ and VAM $(53.3 \%)$ by the respondents, while, FFS respondents did not know about to PSB application (63.3\%) and VAM application (46.7\%). Most of the WMD respondents know about the azotobacter (50.0\%) and PSB (50.0\%) biofertilizer application under INM environmental aspects, while don't know response was expressed to azospirillum application (73.3\%) followed by VAM (68.3\%) application and micronutrient (55.0\%) application by WMD respondents. A majority $(66.7 \%)$ of the ACD respondents expressed response to biofertilizer application as "know" to the micronutrients application followed by PSB (41.7\%) and VAM (31.7\%), respectively and don't know response was to application of azotobacter (76.7\%), azospirillum (73.3\%) and VAM (68.3\%). The HCD respondents had knowledge about PSB (65.6\%), micronutrients $(62.5 \%)$, azotobacter $(56.3 \%)$ and azospirillum (50.0\%) and 71.9 per cent respondents did not know about the VAM biofertilizer application followed by Azospirillum (50.00\%) and Azotobactor $(43.8 \%)$ under INM. The overall response from the respondents regarding biofertilizer application was know to micronutrients (58.5\%) followed by Azotobacter (54.2\%) while, did not know was expressed to VAM (62.7\%), PSB (53.8\%) and Azospirillum $(51.4 \%)$. The respondents were don't know the application of these fertilizers under INM practices. The special features of the findings observed were that the practice of applying biofertiltizer, micronutrients and azotobacter was known to majority farmers. Thus, when special efforts were made by the way of training, demonstration, field visits, exhibition, study tour etc., as project activities, farmers acquire more knowledge about new technology. Further, the findings revealed that the practice of applying biofertilizer: VAM, PSB and azospirillum was not known to majority farmers. Only a very few farmers have possessed knowledge about it. Thus, the practices which are new, not practiced from the past and not a traditional method are less known to farm women. The reason is that these are new practices and require additional efforts to know them. This provides an ample scope for the improvement of knowledge among respondents.

The data presented in the table-15 gives the detailed account on knowledge of fertilizer (NPK) application under INM practices. Cent percent of the respondents had knowledge about the basal dosage during transplanting followed by top dressing 25 days after transplanting $(91.7 \%)$ and top dressing 45 days after transplanting (80.0\%). The WMD respondents expressed as "know" to the basal dosage fertilizer application during transplanting $(91.7 \%)$ and top dressing 25 days after transplanting $(90.0 \%)$. With respect to ACD 88.3 per cent of the respondents had knowledge about the top dressing fertilizer application 45 days after transplanting followed by 85.0 per cent on top dressing 25 days after transplanting and 63.3 per cent on basal dosage fertilizer application during transplanting. In case of HCD, the respondents had knowledge about the top dressing fertilizer application 45 days after transplanting (93.8\%) followed by 87.5 per cent on the top dressing fertilizer application 25 days after transplanting 75.0 per cent regarding basal dose during transplanting and 25.0 per cent of the respondents "don't know" about the basal dosage fertilizer application during transplanting. In general, the respondents did know about the NPK fertilizer application 25 days after transplanting (88.7\%), 45 days after transplanting $(86.8 \%)$ and basal dosage fertilizer application during transplanting $(83.5 \%)$. Only a few respondents expressed as 
"don't know" to fertilizer application regarding top dressing 45 days after transplanting (6.3\%), basal dosage fertilizer application during transplanting (8.3\%) and top dressing 25 days after transplanting (15.0\%) by the HCD, WMD and ACD respondents, respectively. Due to the educational activities taken up by the project staff in FFS, WMD, ACD, and HCD majority of farmers had correct knowledge regarding fertilizer (N:P:K) dosage fertilizer application. Further, the technical guidance was made available to the farmers to take up timely operations.

The FFS respondents who had knowledge about the time of basal dosage fertilizer application during transplanting were cent per cent. This was followed by 91.70 per cent, $75.0 \%$ and 63.30 per cent of WMD, HCD and ACD respondents, respectively. Further 91.7 per cent of FFS respondents did know about the time of application top dressing after 25 days of transplanting, followed by 90.0 per cent WMD, 87.50 per cent HCD and 85.00 per cent ACD respondents, respectively. As many as 88.3 per cent of WMD, 87.5 per cent of HCD, 83.3 per cent of ACD and 80.0 per cent of FFS respondents had knowledge about the time of application of top dressing 45 days after transplanting, respectively. The overall response expressed from the respondents as "know" regarding time of application of top dressing 25 days after transplanting was 88.7 per cent, followed by 45 days after transplanting $(84.4 \%)$ and basal dosage during transplanting $(83.5 \%)$ respectively. The response expressed by the respondents as "don't know" regarding top dressing 25 days after transplanting (11.3\%) and 45 days after transplanting (15.6\%) and basal dosage during transplanting 16.5 per cent only. Due to the educational activities taken up by the project staff in FFS, WMD, ACD and HCD majority of the farmers had correct knowledge regarding correct time of fertilizer application. Further, the technical guidance was made available to farmers to take up timely operations.

Almost cent per cent of FFS, WMD and HCD respondents expressed that they had knowledge about pheromone trap with lures followed by ACD respondents (73.3\%). About panchagavya IPM practices the FFS respondents had cent per cent knowledge followed by HCD respondents (81.3\%), WMD respondents (76.7\%) and ACD respondents (61.7\%). As many as 96.9 per cent of HCD respondents did "know" about trap crop marigold (1:10) and mustard (1:10) IPM practices and 95.0 per cent each respondents from FFS and WMD had knowledge about the same practices. Further the ACD, WMD, HCD and FFS respondents did know about the IPM practices of chemical spraying 95.0 per cent, 91.7 per cent, 90.6 per cent and 83.3 per cent, respectively. A great majority (91.7\%) of the ACD respondents had knowledge regarding 4 per cent NSKE sprays of IPM practice followed by 90.60 per cent of HCD, 86.7 per cent of WMD and 76.7 per cent of FFS respondents had knowledge about this practice. In respect of IPM practice of using trichoderma the response expressed as "know" by HCD (81.3 \%), ACD (68.3\%), WMD (58.3\%) and FFS (55.0\%) respondents. As many as 86.7 per cent of WMD, 84.4 per cent of HCD, 80.0 per cent of ACD and 86.7 per cent of FFS respondents "did not know" about NPV.

In general, the overall knowledge regarding IPM practices such as trap crop of marigold (1:10) and mustard (1:10), pheromone trap, chemical spray, $4 \%$ NSKE Spray, panchagavya spray, use of trichoderma, and NPV were 93.4 per cent, 92.5 per cent, 90.1 per cent, 85.8 per cent, 79.7 per cent, 63.7 per cent and 17.9 per cent of the respondents, respectively. Whereas, only 6.6 per cent of 
the respondents "did not know" about trap crop IPM practices of marigold (1:10) and mustard (1:10) followed by pheromone trap with lures $(7.5 \%)$, chemical spray $(9.9 \%), 4$ $\%$ NSKE spray (14.2\%), panchagavya sprays (20.3\%) and trichoderma (36.3\%). Thus, practices which are easy, simple and profitable are known to farmers by CBTMPCS staff created awareness in tank command area regarding IPM practice for controlling pest and diseases and improving income of farmer. But practices which are complex and skill oriented are less known to farmers like NPV (LE).

A great majority of the respondents expressed that they "know" about the agro-eco system analysis components aspects. Cent per cent of the WMD respondents know the difference between beneficial and harmful insects whereas 90.6 per cent of the HCD, 78.3 per cent FFS, and 68.3 per cent of ACD respondents did know about the same aspects. As many as, 93.3 per cent of FFS, 87.5 per cent of HCD, 86.7 per cent of ACD and 81.7 per cent of WMD respondents had knowledge about the difference between pest and disease. Further, knowledge on the difference between insecticide and fungicide was observed with ACD $(85.00 \%)$ respondents followed by WMD (76.7 \%), HCD (75.07 \%) and FFS (70.00 \%) respondents, respectively. The overall knowledge level about agro-eco system analysis components such as difference between pest and diseases was observed with 87.3 per cent of the respondents and the difference between beneficial and harmful insects with 83.5 per cent of the respondents. This was followed by 76.5 per cent of the respondents did know about the difference between insecticide and fungicide.

A few number of the respondents expressed that they "did not know" the difference between pest and diseases $(12.7 \%)$ under agro-eco system analysis components, followed by difference between beneficial and harmful insects $(16.5 \%)$ and difference between insecticide and fungicide $(23.1 \%)$ by the respondents.

All these facts indicate that there was significant gain in the knowledge level of farmers in respect of AESA. The proper guidance of the project staff under the project implies that when special education and awareness efforts put forth by way of training, exhibition, group discussion and meeting, workshops are made, it is possible to increase the knowledge level. For this the reason may be that creation of training environment in which the farmers were exposed to the messages of new technologies supported with different teaching aids like posters, charts, samples and also empowerment of farming members like group discussion and skill demonstrations with the observation and analysis of the agro-ecosystem. In such an environment all the powerful sensory organs are involved and also the individuals were given an opportunity to discuss in group and present their observations immediately after recording the observations in the presence of the trainer. This has resulted in increased knowledge of the TMI members.

It could be seen that, a large majority of the respondents had knowledge about the deep ploughing technology by the respondents of FFS (93.3 \%), HCD (90.6\%) and WMD $(86.7 \%)$ and ACD (86.7\%). In case of the use of resistant varieties 75.00 per cent of the HCD respondents had knowledge followed by WMD (70.0 \%), FFS (65.0\%) and ACD $(63.3 \%)$ respondents, respectively. However, 96.9 per cent of the HCD respondents had knowledge regarding changing of cropping pattern technology and similar trend is seen with respect to WMD (93.3\%), ACD (90.0 $\%)$ and FFS $(88.3 \%)$ respondents. 
Table.1 Overall Knowledge level of participant TMI members on Technological and Environmental aspects

\begin{tabular}{|c|c|c|c|c|c|c|c|c|c|c|c|c|}
\hline \multirow[t]{2}{*}{$\begin{array}{l}\text { Sl. } \\
\text { No. }\end{array}$} & \multirow[t]{2}{*}{ Variable } & \multirow[t]{2}{*}{ Categories } & \multicolumn{2}{|c|}{ FFS $\left(n_{1}=60\right)$} & \multicolumn{2}{|c|}{ WMD $\left(n_{2}=60\right)$} & \multicolumn{2}{|c|}{$\operatorname{ACD}\left(n_{3}=60\right)$} & \multicolumn{2}{|c|}{$\operatorname{HCD}\left(n_{4}=32\right)$} & \multicolumn{2}{|c|}{$\begin{array}{c}\text { Total } \\
(n=212)\end{array}$} \\
\hline & & & No. & $\%$ & No. & $\%$ & No. & $\%$ & No. & $\%$ & No. & $\%$ \\
\hline \multirow[t]{2}{*}{1} & Technological aspects & Low $<15.54$ & 10 & 16.67 & 19 & 31.67 & 20 & 33.33 & 5 & 15.63 & 54 & 25.47 \\
\hline & Mean $=16.28$ & $\begin{array}{l}\text { Medium 15.54- } \\
17.02\end{array}$ & 31 & 51.67 & 26 & 43.33 & 27 & 45.00 & 17 & 53.13 & 101 & 47.64 \\
\hline \multirow{2}{*}{2} & Mean $=22.34$ & $\begin{array}{l}\text { Medium } 21.28 \text { - } \\
23.40\end{array}$ & 23 & 38.33 & 23 & 38.33 & 11 & 18.33 & 12 & 37.50 & 69 & 32.55 \\
\hline & $\mathrm{SD}=2.49$ & High $>23.40$ & 32 & 53.33 & 17 & 28.33 & 11 & 18.33 & 16 & 50.00 & 76 & 35.85 \\
\hline \multirow[t]{2}{*}{3} & Overall Knowledge & Low $<37.25$ & 8 & 13.33 & 22 & 36.67 & 35 & 58.33 & 5 & 15.63 & 70 & 33.02 \\
\hline & Mean $=38.62$ & $\begin{array}{l}\text { Medium } 37.25 \text { - } \\
39.99\end{array}$ & 11 & 18.33 & 17 & 28.33 & 10 & 16.67 & 8 & 25.00 & 46 & 21.70 \\
\hline
\end{tabular}

ACD- Arable Crop Demonstration HCD - Horticultural Crop Demonstration 
Table.2 Knowledge Level of Tank Management Institution members about the Agricultural aspects

\begin{tabular}{|c|c|c|c|c|c|c|c|c|c|c|c|c|c|c|c|c|c|c|c|c|c|}
\hline \multirow{4}{*}{$\begin{array}{l}\text { Sl. } \\
\text { No. }\end{array}$} & \multirow[t]{4}{*}{ Particulars } & \multicolumn{16}{|c|}{ Knowledge } & \multirow{2}{*}{\multicolumn{4}{|c|}{$\begin{array}{c}\begin{array}{c}\text { Overall } \\
\text { Knowledge }\end{array} \\
\begin{array}{c}\text { Total } \\
(\mathbf{n}=212)\end{array}\end{array}$}} \\
\hline & & \multicolumn{4}{|c|}{ FFS $\left(n_{1}=60\right)$} & \multicolumn{4}{|c|}{ WMD $\left(n_{2}=60\right)$} & \multicolumn{4}{|c|}{$\operatorname{ACD}\left(\mathbf{n}_{3}=60\right)$} & \multicolumn{4}{|c|}{$\operatorname{HCD}\left(\mathbf{n}_{4}=32\right)$} & & & & \\
\hline & & \multicolumn{2}{|c|}{ Know } & \multicolumn{2}{|c|}{$\begin{array}{l}\text { Don't } \\
\text { know }\end{array}$} & \multicolumn{2}{|c|}{ Know } & \multicolumn{2}{|c|}{$\begin{array}{l}\text { Don't } \\
\text { know }\end{array}$} & \multicolumn{2}{|c|}{ Know } & \multicolumn{2}{|c|}{$\begin{array}{l}\text { Don't } \\
\text { know }\end{array}$} & \multicolumn{2}{|c|}{ Know } & \multicolumn{2}{|c|}{$\begin{array}{l}\text { Don't } \\
\text { know }\end{array}$} & \multicolumn{2}{|c|}{ Know } & \multicolumn{2}{|c|}{$\begin{array}{l}\text { Don't } \\
\text { know }\end{array}$} \\
\hline & & $F$ & $\%$ & $F$ & $\%$ & $F$ & $\%$ & $F$ & $\%$ & $F$ & $\%$ & $F$ & $\%$ & $F$ & $\%$ & $F$ & $\%$ & $F$ & $\%$ & $F$ & $\%$ \\
\hline I & \multicolumn{21}{|c|}{ TECHNOLOGICAL ASPECTS } \\
\hline 1 & Season-(Kharif/ Rabi) & 45 & 75.00 & 15 & 25.00 & 60 & 100.0 & 0 & 0.00 & 60 & 100.0 & 0 & 0.00 & 32 & 100.0 & 0 & 0.00 & 197 & 92.92 & 15 & 7.08 \\
\hline 2 & Variety & 55 & 91.67 & 5 & 8.33 & 60 & 100.0 & 0 & 0.00 & 39 & 65.00 & 21 & 35.00 & 27 & 84.38 & 5 & 15.63 & 181 & 85.38 & 31 & 14.62 \\
\hline 3 & Seed rate & 51 & 85.00 & 9 & 15.00 & 44 & 73.33 & 16 & 26.67 & 47 & 78.33 & 13 & 21.67 & 28 & 87.50 & 4 & 12.50 & 170 & 80.19 & 42 & 19.81 \\
\hline \multirow[t]{3}{*}{4} & Type of nursery & & & & & & & & & & & & & & & & & & & & \\
\hline & $\begin{array}{l}\text { i. Raised bed } \\
\text { nursery }\end{array}$ & 47 & 78.33 & 13 & 21.67 & 40 & 66.67 & 20 & 33.33 & 55 & 91.67 & 5 & 8.33 & 26 & 81.25 & 6 & 18.75 & 168 & 79.25 & 44 & 20.75 \\
\hline & $\begin{array}{l}\text { ii. Tray method (private } \\
\text { nursery) }\end{array}$ & 37 & 61.67 & 23 & 38.33 & 41 & 68.33 & 19 & 31.67 & 48 & 80.00 & 12 & 20.00 & 23 & 71.88 & 9 & 28.13 & 149 & 70.28 & 63 & 29.72 \\
\hline 5 & Spacing in the main field & 60 & 100.00 & 0 & 0.00 & 44 & 73.33 & 16 & 26.67 & 48 & 80.00 & 12 & 20.00 & 31 & 96.88 & 1 & 3.13 & 183 & 86.32 & 29 & 13.68 \\
\hline \multirow[t]{5}{*}{6} & Method of irrigation & & & & & & & & & & & & & & & & & & & & \\
\hline & i. Ridges and furrows & 55 & 91.67 & 5 & 8.33 & 47 & 78.33 & 13 & 21.67 & 44 & 73.33 & 16 & 26.67 & 28 & 87.50 & 4 & 12.50 & 174 & 82.08 & 38 & 17.92 \\
\hline & ii. Alternate furrow & 49 & 81.67 & 11 & 18.33 & 55 & 91.67 & 5 & 8.33 & 51 & 85.00 & 9 & 15.00 & 32 & 100.0 & 0 & 0.00 & 187 & 88.21 & 25 & 11.79 \\
\hline & iii. Skip furrow & 52 & 86.67 & 8 & 13.33 & 48 & 80.00 & 12 & 20.00 & 54 & 90.00 & 6 & 10.00 & 28 & 87.50 & 4 & 12.50 & 182 & 85.85 & 30 & 14.15 \\
\hline & iv. Broad bed and furrow & 48 & 80.00 & 12 & 20.00 & 44 & 73.33 & 16 & 26.67 & 55 & 91.67 & 5 & 8.33 & 29 & 90.63 & 3 & 9.38 & 176 & 83.02 & 36 & 16.98 \\
\hline \multirow[t]{4}{*}{7} & Type of irrigation & & & & & & & & & & & & & & & & & & & & \\
\hline & i. On and off method & 47 & 78.33 & 13 & 21.67 & 60 & 100.00 & 0 & 0.00 & 49 & 81.67 & 11 & 18.33 & 32 & 100.00 & 0 & 0.00 & 188 & 88.68 & 24 & 11.32 \\
\hline & ii. Flooding & 51 & 85.00 & 9 & 15.00 & 56 & 93.33 & 4 & 6.67 & 45 & 75.00 & 15 & 25.00 & 28 & 87.50 & 4 & 12.50 & 180 & 84.91 & 32 & 15.09 \\
\hline & iii. Drip irrigation & 54 & 90.00 & 6 & 10.00 & 52 & 86.67 & 8 & 13.33 & 47 & 78.33 & 13 & 21.67 & 28 & 87.50 & 4 & 12.50 & 181 & 85.38 & 31 & 14.62 \\
\hline 8 & Frequency of irrigation & 55 & 91.67 & 5 & 8.33 & 60 & 100.00 & 0 & 0.00 & 60 & 100.00 & 0 & 0.00 & 32 & 100.00 & 0 & 0.00 & 207 & 97.64 & 5 & 2.36 \\
\hline
\end{tabular}




\begin{tabular}{|c|c|c|c|c|c|c|c|c|c|c|c|c|c|c|c|c|c|c|c|c|c|}
\hline 9 & No. of irrigation & 55 & 91.67 & 5 & 8.33 & 52 & 86.67 & 8 & 13.33 & 60 & 100.00 & 0 & 0.00 & 29 & 90.63 & 3 & 9.38 & 196 & 92.45 & 16 & 7.55 \\
\hline 10 & Weeding and earthing up & 60 & 100.00 & 0 & 0.00 & 60 & 100.00 & 0 & 0.00 & 60 & 100.00 & 0 & 0.00 & 32 & 100.00 & 0 & 0.00 & 212 & 100.00 & 0 & 0.00 \\
\hline \multirow[t]{4}{*}{11} & Staking & & & & & & & & & & & & & & & & & & & & \\
\hline & $\begin{array}{l}\text { i. At one month after } \\
\text { transplanting }\end{array}$ & 60 & 100.00 & 0 & 0.00 & 46 & 76.67 & 14 & 23.33 & 48 & 80.00 & 12 & 20.00 & 22 & 68.75 & 10 & 31.25 & 176 & 83.02 & 36 & 16.98 \\
\hline & $\begin{array}{l}\text { ii. At two months after } \\
\text { transplanting }\end{array}$ & 56 & 93.33 & 4 & 6.67 & 42 & 70.00 & 18 & 30.00 & 50 & 83.33 & 10 & 16.67 & 26 & 81.25 & 6 & 18.75 & 174 & 82.08 & 38 & 17.92 \\
\hline & $\begin{array}{l}\text { iii. At three months } \\
\text { transplanting }\end{array}$ & 60 & 100.00 & 0 & 0.00 & 44 & 73.33 & 16 & 26.67 & 47 & 78.33 & 13 & 21.67 & 20 & 62.50 & 12 & 37.50 & 171 & 80.66 & 41 & 19.34 \\
\hline
\end{tabular}
ACD-Arable Crop Demonstration HCD - Horticultural Crop Demonstration

Table.3 Knowledge Level of Tank Management Institution members about Environmental aspects

\begin{tabular}{|c|c|c|c|c|c|c|c|c|c|c|c|c|c|c|c|c|c|c|c|c|c|}
\hline \multirow[t]{3}{*}{ II } & \multirow[t]{3}{*}{ ENVIRONMENTAL ASPECTS } & \multicolumn{16}{|c|}{ Knowledge } & \multirow{2}{*}{\multicolumn{4}{|c|}{$\begin{array}{c}\text { Overall Knowledge } \\
\text { Total }(\mathrm{n}=212)\end{array}$}} \\
\hline & & \multicolumn{4}{|c|}{ FFS $\left(\mathbf{n}_{1}=60\right)$} & \multicolumn{4}{|c|}{ WMD $\left(\mathbf{n}_{2}=60\right)$} & \multicolumn{4}{|c|}{$\operatorname{ACD}\left(\mathbf{n}_{3}=60\right)$} & \multicolumn{4}{|c|}{$\operatorname{HCD}\left(\mathbf{n}_{4}=32\right)$} & & & & \\
\hline & & \multicolumn{2}{|c|}{ Know } & \multicolumn{2}{|c|}{$\begin{array}{l}\text { Don't } \\
\text { know }\end{array}$} & \multicolumn{2}{|c|}{ Know } & \multicolumn{2}{|c|}{$\begin{array}{l}\text { Don't } \\
\text { know }\end{array}$} & \multicolumn{2}{|c|}{ Know } & \multicolumn{2}{|c|}{$\begin{array}{l}\text { Don't } \\
\text { know }\end{array}$} & \multicolumn{2}{|c|}{ Know } & \multicolumn{2}{|c|}{$\begin{array}{l}\text { Don't } \\
\text { know }\end{array}$} & \multicolumn{2}{|c|}{ Know } & \multicolumn{2}{|c|}{$\begin{array}{l}\text { Don't } \\
\text { know }\end{array}$} \\
\hline (A) & Integrated Nutrient Management & & & & & & & & & & & & & & & & & & & & \\
\hline \multirow[t]{6}{*}{1} & Organic Manures & $\boldsymbol{F}$ & $\%$ & $\boldsymbol{F}$ & $\%$ & $\boldsymbol{F}$ & $\%$ & $\boldsymbol{F}$ & $\%$ & $\boldsymbol{F}$ & $\%$ & $\boldsymbol{F}$ & $\%$ & $\boldsymbol{F}$ & $\%$ & $\boldsymbol{F}$ & $\%$ & $\boldsymbol{F}$ & $\%$ & $\boldsymbol{F}$ & $\%$ \\
\hline & a. Tank silt (t/ac) & 60 & 100.0 & 0 & 0.0 & 54 & 90.0 & 6 & 10.0 & 60 & 100.0 & 0 & 0.0 & 28 & 87.5 & 4 & 12.5 & 202 & 95.3 & 10 & 4.7 \\
\hline & b. FYM/Compost (t/ac) & 60 & 100.0 & 0 & 0.0 & 60 & 100.0 & 0 & 0.0 & 60 & 100.0 & 0 & 0.0 & 32 & 100.0 & 0 & 0.0 & 212 & 100.0 & 0 & 0.0 \\
\hline & c. Vermicompost (t/ac) & 60 & 100.0 & 0 & 0.0 & 52 & 86.7 & 8 & 13.3 & 48 & 80.0 & 12 & 20.0 & 32 & 100.0 & 0 & 0.0 & 192 & 90.6 & 20 & 9.4 \\
\hline & d. Green manure (t/ac) & 49 & 81.7 & 11 & 18.3 & 52 & 86.7 & 8 & 13.3 & 51 & 85.0 & 9 & 15.0 & 32 & 100.0 & 0 & 0.0 & 184 & 86.8 & 28 & 13.2 \\
\hline & e. Neem cake (kgs/ac) & 52 & 86.7 & 8 & 13.3 & 57 & 95.0 & 3 & 5.0 & 38 & 63.3 & 22 & 36.7 & 28 & 87.5 & 4 & 12.5 & 175 & 82.5 & 37 & 17.5 \\
\hline \multirow[t]{6}{*}{2} & Bio-Fertilizers & & & & & & & & & & & & & & & & & & & & \\
\hline & a. Azotobacter (kgs/ac) & 53 & 88.3 & 7 & 11.7 & 30 & 50.0 & 30 & 50.0 & 14 & 23.3 & 46 & 76.7 & 18 & 56.3 & 14 & 43.8 & 115 & 54.2 & 97 & 45.8 \\
\hline & b. Azosprillum (kgs/ac) & 55 & 91.7 & 5 & 8.3 & 16 & 26.7 & 44 & 73.3 & 16 & 26.7 & 44 & 73.3 & 16 & 50.0 & 16 & 50.0 & 103 & 48.6 & 109 & 51.4 \\
\hline & c. PSB (kgs/ac) & 22 & 36.7 & 38 & 63.3 & 30 & 50.0 & 30 & 50.0 & 25 & 41.7 & 35 & 58.3 & 21 & 65.6 & 11 & 34.4 & 98 & 46.2 & 114 & 53.8 \\
\hline & d. VAM (Kgs/ac) & 32 & 53.3 & 28 & 46.7 & 19 & 31.7 & 41 & 68.3 & 19 & 31.7 & 41 & 68.3 & 9 & 28.1 & 23 & 71.9 & 79 & 37.3 & 133 & 62.7 \\
\hline & e. Micro nutrients(kgs/ac) & 37 & 61.7 & 23 & 38.3 & 27 & 45.0 & 33 & 55.0 & 40 & 66.7 & 20 & 33.3 & 20 & 62.5 & 12 & 37.5 & 124 & 58.5 & 88 & 41.5 \\
\hline
\end{tabular}




\begin{tabular}{|c|c|c|c|c|c|c|c|c|c|c|c|c|c|c|c|c|c|c|c|c|c|}
\hline \multirow[t]{5}{*}{3} & \multicolumn{21}{|l|}{ Fertilizer N:P:K } \\
\hline & a. Basal dosage during transplanting (Kgs/acre) & 60 & 100.0 & 0 & 0.0 & 55 & 91.7 & 5 & 8.3 & 38 & 63.3 & 22 & 36.7 & 24 & 75.0 & 8 & 25.0 & 177 & 83.5 & 35 & 16.5 \\
\hline & b. Top dressing (Kgs/acre) & & & & & & & & & & & & & & & & & & & & \\
\hline & i. 25 days after transplanting & 55 & 91.7 & 5 & 8.3 & 54 & 90.0 & 6 & 10.0 & 51 & 85.0 & 9 & 15.0 & 28 & 87.5 & 4 & 12.5 & 188 & 88.7 & 24 & 11.3 \\
\hline & ii. 45 days after transplanting & 48 & 80.0 & 12 & 20.0 & 53 & 88.3 & 7 & 11.7 & 53 & 88.3 & 7 & 11.7 & 30 & 93.8 & 2 & 6.3 & 184 & 86.8 & 28 & 13.2 \\
\hline 4 & Time of application & & & & & & & & & & & & & & & & & & & & \\
\hline & a. Basal dosage during transplanting (Kgs/acre) & 60 & 100.0 & 0 & 0.0 & 55 & 91.7 & 5 & 8.3 & 38 & 63.3 & 22 & 36.7 & 24 & 75.0 & 8 & 25.0 & 177 & 83.5 & 35 & 16.5 \\
\hline & b. Top dressing (Kgs/acre) & & & & & & & & & & & & & & & & & & & & \\
\hline & i. 25 days after transplanting & 55 & 91.7 & 5 & 8.3 & 54 & 90.0 & 6 & 10.0 & 51 & 85.0 & 9 & 15.0 & 28 & 87.5 & 4 & 12.5 & 188 & 88.7 & 24 & 11.3 \\
\hline & ii. 45 days after transplanting & 48 & 80.0 & 12 & 20.0 & 53 & 88.3 & 7 & 11.7 & 50 & 83.3 & 10 & 16.7 & 28 & 87.5 & 4 & 12.5 & 179 & 84.4 & 33 & 15.6 \\
\hline (B) & IPM practices & $F$ & $\%$ & $F$ & $\%$ & $\boldsymbol{F}$ & $\%$ & $\boldsymbol{F}$ & $\%$ & $F$ & $\%$ & $\boldsymbol{F}$ & $\%$ & $\boldsymbol{F}$ & $\%$ & $\boldsymbol{F}$ & $\%$ & $\boldsymbol{F}$ & $\%$ & $\boldsymbol{F}$ & $\%$ \\
\hline 1 & Trichoderma (Kgs/ac) & 33 & 55.0 & 27 & 45.0 & 35 & 58.3 & 25 & 41.7 & 41 & 68.3 & 19 & 31.7 & 26 & 81.3 & 6 & 18.8 & 135 & 63.7 & 77 & 36.3 \\
\hline 2 & Trap Crop i)Marigold(1:10) ii)Mustard(1:10) & 57 & 95.0 & 3 & 5.0 & 57 & 95.0 & 3 & 5.0 & 53 & 88.3 & 7 & 11.7 & 31 & 96.9 & 1 & 3.1 & 198 & 93.4 & 14 & 6.6 \\
\hline 3 & 4\%NSKE (No. of Sprays) & 46 & 76.7 & 14 & 23.3 & 52 & 86.7 & 8 & 13.3 & 55 & 91.7 & 5 & 8.3 & 29 & 90.6 & 3 & 9.4 & 182 & 85.8 & 30 & 14.2 \\
\hline 4 & Panchagavya (No. of Sprays) & 60 & 100.0 & 0 & 0.0 & 46 & 76.7 & 14 & 23.3 & 37 & 61.7 & 23 & 38.3 & 26 & 81.3 & 6 & 18.8 & 169 & 79.7 & 43 & 20.3 \\
\hline 5 & Pheromone trap (Nos) with lures & 60 & 100.0 & 0 & 0.0 & 60 & 100.0 & 0 & 0.0 & 44 & 73.3 & 16 & 26.7 & 32 & 100.0 & 0 & 0.0 & 196 & 92.5 & 16 & 7.5 \\
\hline 6 & NPV (LE) & 13 & 21.7 & 47 & 78.3 & 8 & 13.3 & 52 & 86.7 & 12 & 20.0 & 48 & 80.0 & 5 & 15.6 & 27 & 84.4 & 38 & 17.9 & 174 & 82.1 \\
\hline \multirow[t]{2}{*}{7} & Chemical spray & 50 & 83.3 & 10 & 16.7 & 55 & 91.7 & 5 & 8.3 & 57 & 95.0 & 3 & 5.0 & 29 & 90.6 & 3 & 9.4 & 191 & 90.1 & 21 & 9.9 \\
\hline & $\begin{array}{lll}\text { AGRO-ECO } & \text { SYSTEM } & \text { ANALYSIS } \\
\text { COMPONENTS } & & \end{array}$ & & & & & & & & & & & & & & & & & & & & \\
\hline 8 & $\begin{array}{l}\text { Do you know the difference between beneficial and } \\
\text { harmful insects? }\end{array}$ & 47 & 78.3 & 13 & 21.7 & 60 & 100.0 & 0 & 0.0 & 41 & 68.3 & 19 & 31.7 & 29 & 90.6 & 3 & 9.4 & 177 & 83.5 & 35 & 16.5 \\
\hline 9 & $\begin{array}{l}\text { Do you know the difference between pest and } \\
\text { disease? }\end{array}$ & 56 & 93.3 & 4 & 6.7 & 49 & 81.7 & 11 & 18.3 & 52 & 86.7 & 8 & 13.3 & 28 & 87.5 & 4 & 12.5 & 185 & 87.3 & 27 & 12.7 \\
\hline \multirow[t]{2}{*}{10} & $\begin{array}{l}\text { Do you know the difference between insecticide and } \\
\text { fungicide? }\end{array}$ & 42 & 70.0 & 18 & 30.0 & 46 & 76.7 & 14 & 23.3 & 51 & 85.0 & 9 & 15.0 & 24 & 75.0 & 8 & 25.0 & 163 & 76.9 & 49 & 23.1 \\
\hline & OTHER TECHNOLOGIES & & & & & & & & & & & & & & & & & & & & \\
\hline 11 & Deep ploughing & 56 & 93.3 & 4 & 6.7 & 52 & 86.7 & 8 & 13.3 & 52 & 86.7 & 8 & 13.3 & 29 & 90.6 & 3 & 9.4 & 189 & 89.2 & 23 & 10.8 \\
\hline 12 & Use of resistant varieties & 39 & 65.0 & 21 & 35.0 & 42 & 70.0 & 18 & 30.0 & 38 & 63.3 & 22 & 36.7 & 24 & 75.0 & 8 & 25.0 & 143 & 67.5 & 69 & 32.5 \\
\hline 13 & Changing of cropping pattern & 53 & 88.3 & 7 & 11.7 & 56 & 93.3 & 4 & 6.7 & 54 & 90.0 & 6 & 10.0 & 31 & 96.9 & 1 & 3.1 & 194 & 91.5 & 18 & 8.5 \\
\hline
\end{tabular}
ACD- Arable Crop Demonstration HCD - Horticultural Crop Demonstration 
In general, it was noticed that, 91.5 per cent respondents had knowledge about the changing of cropping pattern technology followed by 89.2 per cent respondents about deep ploughing technology and 67.5 per cent respondents about using resistant varieties. It was found that only 8.5 per cent of the respondents "did not know" about the changing of cropping pattern technology followed by deep ploughing $(10.8 \%)$ and use of resistant varieties $(32.5 \%)$. The educational activities conducted under project and proper guidance of the agricultural specialist regarding selection or choosing the varieties and agronomic practices influence farmers to acquire knowledge regarding above specified aspects and another reason may be that it is an age old practice followed by farmers. These factors might have been resulted in increasing knowledge of the TMI members. The information given in FFS, WMD, ACD and HCD might have helped them to acquire knowledge about crop rotation in tank command area. Hence, it is logical to draw inference from the above discussion that the practices which are complex and difficult to remember are less known to farmers, on the other hand practices which are simple were known to farmers to a greater extent and at the same time creation of awareness through educational activities was the major factor for dissemination of technologies through FFS, WMD, ACD and HCD. The above results are conformity with the findings of Naghabushanam (1996), Naresh (1996), Venkatesh Gandhi et al., (2008) and Sathasivam et al., (2009).

\section{References}

Ahmed Zamir, S. K. and Phillip, H., 1999, Effectiveness of training of farm women in Andaman and Nicobar Islands. Madras Agric. J., 86 (1-3): 154157.

Borkar, M. M., Chothe, G. D. and
LANJEWAR. A. D., 2000, Characteristics of farmers influencing their knowledge about use of biofertilizers. Mah. J. Ext. Edu.19: 59-63.

Gogoi, M.E., Phukan and R. K., Talukdar 2000, Impact of farmers training programme on adoption of rice production technology by farmers. Mah. J. Ext. Edu. 19: 232 -238.

Kubde, V.R., Bhople, S.R. and Tekale, V.S., 2000, Knowledge and adoption of cultivation and storage practices of potato. Mah. J. Ext. Edu.,19: 293-298.

Naghabushanam, K., 1996, Impact of Training on Farm Women under Women and Youth Training Extension Project. Research Report, TNAU, Coimbatore.

Naresh, N.T., 1996, A Study on Knowledge and Adoption of Improved Sericulture Practices among Trained Women in Bangalore Rural District. M.Sc. (Agri.) Thesis, (Unpublished), Uni. of Agric. Sci., Bangalore.

Sasidhar Reddy, R., Prasad, S.V., Ramachandra Reddy, D.and SASTRY, T.P., 2007, Knowledge and farming performance of tomato farmers in Chiittoor district of Andra Pradesh $J$. Res.ANGRAU35(2): 91-92.

Sathasivam, S. Thyagarajan and Parthasarathi, S., 2009, Knowledge level of paddy growers about IPM Biofertilizers practices, J. Ext. Edu., 21(1): 41944196.

Shinde, S.B., 2002, knowledge of farmers about improved cultivation practices of groundnut in satar district, Mah. J. Ext. Edu., 21:90-91.

Sudhakar, B and Kanagasabapathi. K., 2002, Awareness and adoption of integrated pest management practices in cotton cultivation. Ind. J. Ext. Edu., 13(3): 3364-3367.

Venkatesh Gandhi, R., Hanchinal, S.N., Krishna, T.V., Shivamurthy, M. and 
Shailaja Hittalmani, 2008, Knowledge level of vegetable growers with respect to IPM practices of tomato crop in Kolar district, Mysore J. Agric. Sci., 43(3): 718-721.

Vinay Kumar, K.V., Natikar, M.S., Nataraju, H.K, Ankaja and Dhananjaya, D., 2009, Knowledge level of rose growers about improved cultivation practices, Mysore J.Agric. Sci.,43(3): 327-529.

Vinod Gupta, Dilip and Dundarswamy, B., 2001, Knowlede of the farmers about improved cultivation practices of Rice in Jammu, Mah. J. Ext. Edu., 20:74-76.

\section{How to cite this article:}

Ashok Doddamani, M. A. Yashashwini and Savitha, C. M. 2021. Knowledge Level of Participant TMI Members on Technological and Environment Aspects. Int.J.Curr.Microbiol.App.Sci. 10(01): 1796-1809.

doi: https://doi.org/10.20546/ijcmas.2021.1001.210 